\title{
Prevalence of Burnout Syndrome in Teachers from Seven Health Courses at the Unirg Foundation and University Center in the Municipality of Gurupi-TO
}

\author{
Vanderson Ramos Mafra, Rosana Rodrigues Alves Miranda, Denise Piccoli de Paula, Sara Falcão \\ de Sousa*, Aline Matos De Carvalho Berto, Eros Silva Cláudio, Jaqueline Cibene, Millena \\ Pereira Xavier, Natallia Moreira Lopes Leão, Saulo José de Lima Júnior, Yara Silveira.
}

\begin{abstract}
This study establishes the incidence of burnout in teachers and the University Center of the foundation of the city of UNIRG Gurupi -TO, using the MBI (Malasch Burnout Inventory). Burnout is a persistent condition and negative work-related, exposed by normal individuals, distinguished by exhaustion, reduced sense of efficacy, reduced motivation and dysfunctional attitudes and behaviors at work. An investigation was conducted with 101 teachers UNIRG the municipality of Gurupi-TO. The data indicated no major incidence of burnout in the sample. The 3 dimensions established by MBI for the syndrome was characterized by $9.9 \%$ in the dimension of emotional exhaustion (EE), $21.78 \%$ in the dimension depersonalization (DE) and $100 \%$ professional achievement in the dimension (RP). Even so, it would be important to create programs that prevent burnout syndrome, to prevent education professionals to get sick. It is also necessary to continue this type of research and to create more complex patterns for the outline of burnout in this specific context.
\end{abstract}

Index Terms - Burnout Syndrome; Teachers; Health Workers.

\section{INTRODUCTION}

A person's quality of life is not only to correlate their physical affection with how much they will achieve survival, but it is about pondering the physical, social, environmental and psychic aspects of this individual. That is, the living condition is not only synthesized in how the subject behaves

Vanderson Ramos Mafra, Pharmacist, Master of Health Sciences, University of Gurupi - UnirG, Gurupi, Tocantins - Brazil

Rosana Rodrigues Alves Miranda, Pharmacist, University of Gurupi UNIRG, Gurupi, Tocantins - Brazil

Denise Piccoli de Paula, Biomedical. Master in Environmental Sciences and Health, University of Gurupi - UnirG, Gurupi, and Tocantins - Brazil

* Sara Falcão de So usa, Pharmaceutical. Master in Human Motricity Science, University of Gurupi - UnirG, Gurupi, and Tocantins - Brazil sarafalcao@unirg.edu.br

Aline Matos de Carvalho Berto Biomedical, Master in Tropical Medicine and Public Health, University of Gurupi - UnirG, Gurupi, Tocantins - Brazil Eros Silva Claúdio, Physical therapist. Orthopedic Trauma Physiotherapy Specialist, University of Gurupi - UnirG, Gurupi, Tocantins - Brazil

Jaqueline Cibene Moreira Borges, Pharmaceutical, PhD in Biodiversity and Biotechnology, University of Gurupi - UnirG, Gurupi, Tocantins - Brazil Millena Pereira Xavier, Pharmaceutical, Master in Public Policy Management, University of Gurupi - UnirG, Gurupi, Tocantins - Brazil

Natallia Moreira Lopes Leão, Pharmaceutical, Master in Tropical Medicine and Public Health, University of Gurupi - UnirG, Gurupi, Tocantins - Brazil

Saulo José de Lima Júnior, Pharmacist, Specialist in Clinical Pharmacology, Medical Scholar, University of Gurupi - UnirG, Gurupi, Tocantins - Brazil

Yara Silveira, Pharmaceutical, Specialist in Pharmaceutical Care, Clinical Pharmacy and Intensive Care, University of Gurupi - UnirG, Gurupi, Tocantins - Brazil in the face of treatments for a given disease, but still in what the life of this sick individual is [1,2] .

Currently one of the factors that most affect the quality of life is stress. It is considered a worldwide health problem being an element of several descriptive and functional researches seeking the origin of its causes, so as to try its minimization through possible solutions. The discovery of factors allows us to intervene in intervention and prevention programs. Among the health problems, stress is present in several professions, including teachers [3-6].

Malaise is evaluated as a problem present in education workers, where it has been associated with an expansion of tension in the exercise of teacher work justified by the presence of violence in the work environment, physical exhaustion, scarcity of material resources and deficiencies in working conditions, related to an advance of responsibilities [4, 7-11].

Therefore, both in the type of teacher's work and in the environment in which he performs his activities there are multiple stressor factors that can cause Burnout syndrome. It was defined as a type of long-lasting stress associated with work situations, resulting from the unalterable and repetitive emotional pressure related to intense involvement with people for prolonged periods. The etiological conception most used in the current studies is socio-psychological, where it clarifies the appearance of the factors of the syndrome as a consequence of the individual characteristics associated with those of the environment and work. The causes that differentiate the syndrome are emotional exhaustion, affective distancing, and professional achievement. This syndrome affects the educational environment and interferes with the achievement of teachers' pedagogical objectives [7, 8, 11-13].

Several investigations have been concerned with finding the origins of Burnout mainly in the teacher population. Its origins consisted of an adjustment of organizational, individual and social factors, and this interaction would produce a perception of low professional appreciation, resulting in Burnout. Similarly, personality types may also be associated with. Idealistic teachers and enthusiastic about their profession are in the risk group, as they are usually more dedicated to work and commits deeply to their activities, feeling depressed when not rewarded for their efforts. Idealization and consequent frustration promote the emergence of Burnout [3, 4, 7-9, 12, 14-16].

Burnout Syndrome (BS) is present today as one of the major psychosocial problems that are affecting professionals from 
various areas, especially teaching. This reality has generated great interest and concern not only of the international scientific community, but also of governmental, educational, business and union entities in Brazil, due to the rigidity of the consequences, both individual and presented by the Syndrome, especially as an interference factor in the interpersonal relationships of the teacher $[11,17]$.

The objective of this work was to evaluate the occurrence of Burnout syndrome in professors of health courses at UNIRG university center, Gurupi-TO municipality, verifying the presence of possible relationships between the syndrome and the general state of health of this population, verifying the degree of emotional exhaustion, depersonalization and decreased personal achievement at work.

Therefore, this survey in this municipality may form a tool of great importance for the provision of functional information that may serve as a guide for conduction, therapy and especially data that allows correcting or develop prophylaxis programs in UNIRG teaching community.

\section{METHODOLOGY}

This is descriptive research, the field with a quantitative approach, making it possible to evaluate the possibility of burnout syndrome (BS) in teachers, based on the data collection performed with the application of the questionnaire.

The research was carried out on campus II of the UnirG University Foundation and Center (UNIRG) located Guanabara Avenue No. 1500, in the municipality of Gurupi, state of the Tocantins, located $220 \mathrm{~km}$ from the capital Palmas.

The target population consisted of 101 teachers who are teaching. The courses selected for research were Nursing, Pharmacy, Physiotherapy, Physical Education, Dentistry, Psychology, and Medicine. The institution offers 14 courses being only 7 in the area defined for research (health).

The inclusion criteria were: To be regularly linked and performing teaching activities; It is present at the time and place of this research; Teachers who work only in the health area; Be a professor at UnirG; Have signed and agreed to the Informed Consent Form (ICF).

The inclusion criteria were: To be regularly linked and performing teaching activities; It is present at the time and place of this research; Teachers who work only in the health area; Be a professor at UnirG; Have signed and agreed to the Informed Consent Form (ICF).

For the evaluation of the occurrence of Burnout syndrome (BS) the Maslach Burnout Inventory - Human Services Survey (MBI-HSS) was adapted by the researcher, which is the most used instrument to analyze burnout in workers who need to maintain direct contact with other people. This questionnaire evaluates how the individual experiences his work, consisting of 20 questions, disseminated in three dimensions: (a) dimension of emotional exhaustion (b) dimension of depersonalization (c) dimension reduction of personal achievement at work. Each question presents a score scale ranging from one to seven but is commonly used in the version in Portuguese one the score that ranges from one to five. The presence of high scores in emotional exhaustion and depersonalization and low scores in personal performance indicate high burnout levels.

The informed Consent term (TCLE) was delivered to all, after explanations and justification about the research, as well as all doubts that occurred, only after they answered the questionnaire according to class MBI.

The data were analyzed descriptively. The MBI-HS system obtained the index of each dimension (emotional exhaustion, depersonalization and decreased personal achievement at work) adding the answers referring to each of these dimensions, in addition to the total score, through the sum of all responses. The research was approved by the Research Ethics Committee (Brazil platform) under the opinion of number 402,143 on September 20, 2013.

\section{RESULTS AND DISCUSSION}

The research was conducted with 101 professors from 7 health courses of the UnirG University Center (UNIRG) municipality of Gurupi.

The results were surprising since $100 \%$ of the sample was not expected to present individually satisfied with the profession.

Burnout syndrome (BS) is characterized by a developed state after a period of lasting stress, being of a working character and developing in stages.

Thus, this study showed that university professors are predisposed to develop the syndrome. However, a better characterization of this population, with larger samples and different types of institutions in all spheres is necessary in order to better define the occurrence of this syndrome in this population [16].

Interventions should aim at the search for alternatives for possible modifications, not only in the microsocial sphere of work and interpersonal relationships but also in the wide range of macroorganizational factors that determine constituent aspects of culture organizational and social activity in which the teacher carries out his professional activity $[4,8,12,18]$.

Different from the results found in the present study, Carloto (2004) [18] e Sousa (2006) [19] in conducting their research with university professors found a prevalence of the dimensions of the MBI in their respective samples.

There was almost no research conducted with university professors, most of them referred to the state, municipal and private schools. In the researches found, most of them were found to have high rates of emotional exhaustion and depersonalization.

The absence of Burnout stands out in 101 subjects (100\%) who participated in the study; 12 subjects $(11.88 \%)$ are at risk (two of the three criteria fulfilled); and 89 subjects $(88.12 \%$ ) they showed no important classification in any of the dimensions, not configuring diagnostic criteria and much less risk situation for Burnout in this study (absence of Burnout) as presented in Figure 1. 


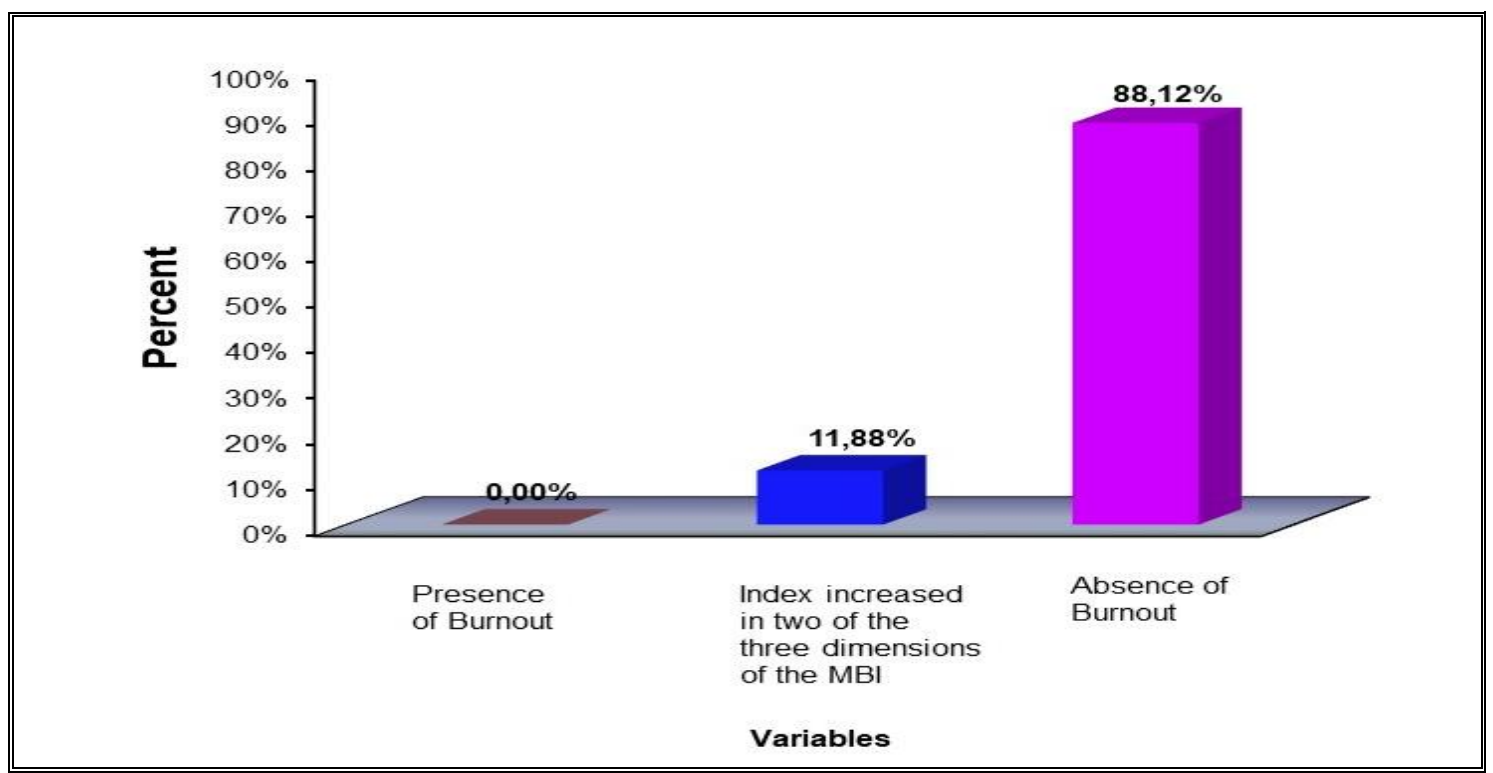

Fig 1. Distribution of the 101 teachers of Unirg health courses in Gurupi (TO) as regards the presence of Burnout according to the MBI classification.

Although there is a profile established by Burnout scholars for individuals with great predisposition to the onset of the syndrome, the research indicates that it is not possible to start from the individual diagnosis of each characteristic, due to the appearance of Burnout depend on professional, personal, organizational and social aspects and the analysis of the positive and negative points of these aspects together is that define the individual's state.

The only research conducted with university professors who did not present high levels of Burnout was that of [16].

The results of the present study were positive in relation to UNIRG teachers regarding this pathology, where it did not present the presence of the disease in any teacher. A fact that can probably be justified by the teaching time because the sample consisted of relatively new teachers in the teaching career $(41.58 \%$ have up to 6 years of the profession). The results of the present study were positive in relation to UNIRG teachers regarding this pathology, where it did not present the presence of the disease in any teacher. A fact that can probably be justified by the teaching time because the sample consisted of relatively new teachers in the teaching career ( $41.58 \%$ have up to 6 years of the profession).

It should be noted, however, that there is no consensus among the researchers of the phenomenon according to the values presented in their respective dimensions and the incidence of burnout, nor in relation to the order of onset of symptoms. Thus this study considers conceptual divergences based on more recent data. It should be noted, however, that there is no consensus among the researchers of the phenomenon according to the values presented in their respective dimensions and the incidence of burnout, nor in relation to the order of onset of symptoms. Thus this study considers conceptual divergences based on more recent data.

Another probable discussion may arise regarding the results of this study: is " $n$ " small? Perhaps an investigation with more courses, with greater depth and scope would clarify whether the present study contemplated a focal cause, or is not so worrying, is the institutional issue so positive?

Debating school failure, inclusion, evasion, and other issues of great importance only makes sense when the educator feels his individual qualities and his valued category. Which causes enthusiasm, commitment, and participation. Thus, the importance of the findings of the research presented, and the need for more active movements, suggesting the creation of a "Burnout Syndrome Prevention and Treatment Program - PPTSB", to be incorporated inside and outside school systems. Medical support - immediate psychological, continuous education focused on prevention, and adequacy in the internal ecology of schools, and in their "surroundings", would be of great significance and compatible with projects already under discussion and studies in the Brazilian Society.

Although this study was conducted with the participation of a little less than half of the institution's teachers, a fact that may predispose to a limitation, thus it can be said that its results suggest the need to conduct other studies in the health area mental with this population. In addition, it is important to recommend the adoption of interference methods that will be taken in order to adapt to the better quality of life and work to professionals in the field of education, emphasizing mental health, for effective execution of Profession. Mental health in the work environment should be a priority, always aiming at the rescue of the value of the human being and the significance of work in people's lives.

An important aspect is that UNIRG teachers teach classes in several courses and thus can provoke a bias in the results of the present study in relation to the comparison between the courses, since the courses where data collection was made first presented a greater number of teachers compared to the 
others. As for example, data collection was performed with 24 professors of the medical course already in the nursing course that was one of the last ones were only 4. Another aspect is rejection in making the research decrease the sample amount. Thus, it was unnecessary to compare the courses in relation to BS.

The relationship between teaching time and Burnout syndrome found in the proposed objectives was expendable since there was no prevalence of the disease in the population studied.

It is also worth mentioning that this research is a pioneer in the southern region of Tocantins, especially when it comes to the analysis of Burnout syndrome in university professors. However, it needs to rescue the important role of teachers in society in general, providing him with minimum health conditions and their proper professional recognition, offering him his own recognition as a teacher, with forms of appreciation, growth, and progression in their respective positions, respecting the true needs and desires of the category.

\section{CONCLUSION}

The present study evaluated the occurrence of burnout syndrome in teachers from 7 health courses of the Foundation and UnirG University Center in the municipality of Gurupi-TO, verifying the presence of possible relationships between the syndrome and the general state of health of this population through the subscales of the MBI.

It found that: $100 \%$ of the teachers were not found to burnout; $11.88 \%$ are at risk, and $88.12 \%$ showed no significant classification in any of the dimensions.

From the above, the need to conduct other studies with new foci and variables is emphasized in order to increase the understanding of Burnout syndrome and the coping tactics used by teachers. In such a way, one can think of exclusive strategies directed to the development of educational actions for those who consider themselves affected by Burnout or even those who, did not experience its effects, decide to learn more appropriate actions to face work stress, in a preventative character to the emergence of this syndrome.

However, it is thought that the prevention and eradication of Burnout in teachers is not such a solitary act, but should include collective actions between teachers, students, educational institutions and society in general. Actions suggesting that constitute an institutional context that constitutes a more conducive context to the practice of the teaching profession through programs related to the directive and pedagogical teams of schools, in order to provide an institutional space for debates and analyses between teams and teachers. Similarly, activities aimed at teachers, admonishing them about the probable aspects of work-oriented stress and the possibility of evolution of this type of chronic occupational stress called burnout.

Finally, knowing that there are no simple resources for this phenomenon, it is suggested the use of individual actions such as the practice of physical exercises, the reorganization of time, environment for rest in free hours and the conservation of good relationships; and the use of organizational tactics such as consideration, equity, respect and unity, chance of growth within the school and participation in actions, deriving in the health of teachers, avoiding the emergence of burnout and, therefore, improving the quality of services offered, since applying in the quality of the teacher's work means much more than helping professionals, it is actually to leverage the creation and development of future society.

There is no presumption here to exhaust the probable assessments related to the burnout syndrome, but to spark the idea and discussion about such an evident and yet ignored disorder among all, even though no case was found in this institution, but there is a great deal of it. Prevalence in primary, elementary and middle school teachers originated from one of those levels.

\section{ACKNOWLEDGEMENTS}

We thank Normatiza for the collaboration in the consulting of the publication of this work.

\section{REFERENCES}

[1] CHIRICO, Francesco. Modelos de estresse no trabalho para prever a síndrome de Burnout: uma revisão. Annali dell'Istituto superiore di sanita , v. 52, n. 3, p. 443-456, 2016.

[2] CHERNISS C. Professional burnout in human service organizations. New York: Praeger, 1980.

[3] WITTER, P. G. Professos-Estresse: Análise de produção Científica. Psicologia Escolar e Educacional, 7(1):33-46, 2003

[4] SORGEN, Carl H.; MELTON, Teri Denlea; DIAMANDUROS, Terry Davis. Níveis percebidos de estresse e qualidade de vida profissional de professores. The Journal of Faculty Development, v. 34, n. 1, p. 31-36, 2020 .

[5] Holmes ES, Santos, Sr, Almeida, Aaf, ET al. (2017). \& de Arruda Prevalência da síndrome de burnout e fatores associados a professores universitários Arquivos Internacionais de Medicina. P. 10-10.

[6] BENEVIDES-PEREIRA, A. M. T. A Síndrome de Burnout. 2011 Disponível em: <http://www.prt18.mpt.gov.br/eventos/2004/saude_mental/anais/artigo s/2.pdf>. Acesso em: jan., 2011.

[7] DE OLIVEIRA MESSIAS, Inalda Maria et al. Síndrome de burnout em professores de uma escola pública de Petrolina - PE / Síndrome de burnout em professores de uma escola pública de Petrolina-PE. Revista Brasileira de Desenvolvimento, v. 5, n. 5, p. 3856-3866, 2019.

[8] CARLOTTO, Mary Sandra; CÂMARA, Sheila Gonçalves Psychosocial Risks Associated with Burnout Syndrome Among University Professors. Avances en Psicología Latinoamericana, v. 35, n. 3, p. 447-457, 2017.

[9] ARAÚJO, M.T.; SENA, I. P.; VIANA, A. M.; ARAÚJO, M. E Mal-Estar Docente: Avaliação de condições de trabalho e saúde em uma instituição de ensino superior. Rev Baiana Saúde Pública, 29(1): 6-2, 2005.

[10] ROTHE, N., SCHULZE, J., KIRSCHBAUM, C., BUSKE-KIRSCHBAUM, A., PENZ, M., WEKENBORG, MK, \& WALTHER, A. (2020). Distúrbios do sono na síndrome depressiva maior e burnout: uma análise longitudinal. Psychiatry Research, 112868 . 
[11] Moreira, H. D. A., Souza, K. N. D., \& Yamaguchi, M. U. (2018) Burnout syndrome in physicians: a systematic review. Revista Brasileira de Saúde Ocupacional, 43.

[12] CARLOTTO, M. S.; PALAZZO, L. S. Síndrome de burnout e fatores associados: um estudo epidemiológico com professores. Cad. Saúde Pública, Rio de Janeiro, 22 (5): 1017-1026, mai, 2006.

[13] TRIGO, T. R.; TENG, C. T.; HALLAK, J. E. C. Síndrome de burnout ou estafa profissional e os transtornos psiquiátricos. Rev Psiquiatria Clínica, 34 (5); 223-233, 2007.

[14] Holmes ES, Santos, Sr, Almeida, Aaf, et al. (2017). \& de Arruda. Prevalência da síndrome de burnout e fatores associados a professores universitários Arquivos Internacionais de Medicina. P. 10-10.
[15] BERTACI A. (2011). Síndrome de burnout e nível geral de saúde em professores universitários. Neuro- biology. (1): 189-196.

[16] FERENHOF, I.A.; FERENHOF, E.A. Burnout em Professores. ECCOS - Revista Científica - Avaliação e Mudanças - Centro Universitário Nove de Julho - São Paulo, v. 4, n. 1, p. 131/151. 2002.

[17] SOUSA, I. F. Burnout em professores universitários: análise de um modelo mediacional. 2006. 141f. Tese (mestrado em Psicologia) Universidade Católica de Goiás, Goiânia, 2006.

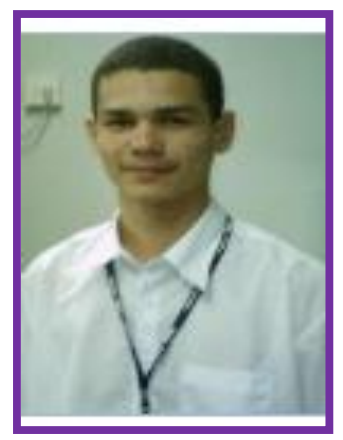

Vanderson Ramos Mafra: He holds a degree from the UNIRG University Center (2010). Specialization in Management in Public, Collective and Family Health (FHP) by the Specific Institute of Research and Graduate Teaching. He has experience in pharmacy, with emphasis on Pharmaceutical Care and Care, Pharmacy and Drugstore management and performance in hospital pharmacy. Drug store owner. He holds a Professional Master's degree in Health Sciences (MPCS) from the Federal University of Tocantins (UFT). Professor of pharmacy course at Gurupi University - UnirG. Councillor of the Regional Pharmacy Council of the State of Tocantins mandate 20/23.

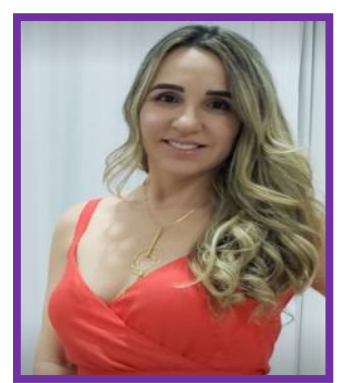

Rosana Rodrigues Alves Miranda: Pharmaceutical. Pedagogue at Unirg University, postgraduate in Hospital Pharmacy; Educational Planning and Methodology of Teaching natural sciences.

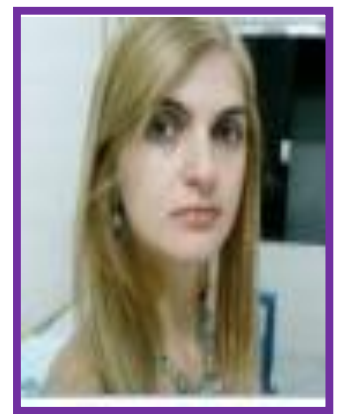

Denise Piccoli de Paula: Master in Environmental Sciences and Health, Gurupi - Tocantins- Brazil. Master's degree in Environmental Sciences and Health from the Pontifical Catholic University of Goiás. He holds a degree in Biological Sciences Medical Modality- Biomedicine, from the Catholic University of Goiás (2000). Specialist in Clinical Analyses from the Integrated Faculties of Jacarépaguá- RJ, in Microbiology, Faculty of Pharmacy of the Federal University of Goiás (2007) and in Public Health from the International College of Curitiba-PR (2005). He works as a on-duty biomedical student at the Transfusion Agency of Gurupi Regional Hospital. Owner and Technical Officer of Labormed Laboratory - Alvorada -TO. 